\title{
The Association between Periodontitis and Human Colorectal Cancer: Genetic and Pathogenic Linkage
}

\author{
Federica Di Spirito ${ }^{1,2}, * \mathbb{C}$, Paolo Toti ${ }^{1,3,4}$, Vincenzo Pilone ${ }^{1,5}$, Francesco Carinci ${ }^{6}$, \\ Dorina Lauritano ${ }^{7}$ (i) and Ludovico Sbordone ${ }^{1,2}$
}

1 Department of Medicine, Surgery and Dentistry "Schola Medica Salernitana”, University of Salerno, Via S. Allende, 84081 Baronissi (Salerno), Italy; capello.totipaolo@tiscali.it (P.T.); vpilone@unisa.it (V.P.); lsbordone@unisa.it (L.S.)

2 Complex Operating Unit of Odontostomatology, Head and Neck Clinical Department, Azienda Ospedaliero-Universitaria San Giovanni di Dio e Ruggi d'Aragona, 84121 Salerno, Italy

3 Private Practice, Via Provinciale 87B, 55041 Camaiore (Lucca), Italy

4 Department of Surgery, University of Pisa, Via Paradisa 2, 56124 Pisa, Italy

5 Complex Operating Unit of General Surgery, Azienda Ospedaliero-Universitaria San Giovanni di Dio e Ruggi d'Aragona, 84121 Salerno, Italy

6 Department of Morphology, Surgery and Experimental Medicine, University of Ferrara, Via Luigi Borsari 46, 44121 Ferrara, Italy; francesco.carinci@unife.it

7 Department of Medicine and Surgery, Centre of Neuroscience of Milan, University of Milano-Bicocca, 20126 Milan, Italy; dorina.lauritano@unimib.it

* Correspondence: fdispirito@unisa.it or dispiritof@yahoo.it

Received: 5 August 2020; Accepted: 14 September 2020; Published: 18 September 2020

\begin{abstract}
Periodontitis has been associated with an increased risk of and mortality associated with human colorectal cancer (CRC). Current evidence attributes such an association to the direct and indirect effects of virulence factors belonging to periodontal pathogens, to inflammatory mediators and to genetic factors. The aims of the study were to assess the existence of a genetic linkage between periodontitis and human CRC, to identify genes considered predominant in such a linkage, thus named leader genes, and to determine pathogenic mechanisms related to the products of leader genes. Genes linking periodontitis and CRC were identified and classified in order of predominance, through an experimental investigation, performed via computer simulation, employing the leader gene approach. Pathogenic mechanisms relating to leader genes were determined through cross-search databases. Of the 83 genes linking periodontitis and CRC, 12 were classified as leader genes and were pathogenically implicated in cell cycle regulation and in the immune-inflammatory response. The current results, obtained via computer simulation and requiring further validation, support the existence of a genetic linkage between periodontitis and CRC. Cell cycle dysregulation and the alteration of the immuno-inflammatory response constitute the pathogenic mechanisms related to the products of leader genes.
\end{abstract}

Keywords: periodontitis; colorectal cancer; bioinformatics

\section{Introduction}

Periodontitis, as defined by Tonetti et al. and by Lang et al., is a "multifactorial microbiallyassociated inflammatory disease" affecting tooth-supporting structures and, ultimately, leading to tooth loss [1-3].

In the last decade, a growing body of evidence has reported the association between periodontitis and a variety of systemic inflammatory conditions and diseases, including atherosclerosis, diabetes, rheumatoid arthritis, and inflammatory bowel disease (IBD) [4-6]. Most notably, recent findings have 
also associated periodontitis with solid cancers, such as malignant neoplasms of the prostate, breast, lung, pancreas, and kidney [6,7]. Moreover, periodontitis has been associated with an increased risk of colorectal adenoma and colorectal cancer (CRC) development $[8,9]$ and to an increased mortality from CRC [10].

Human colorectal cancer accounts for approximately ten percent of new cancer cases worldwide in males and $9.2 \%$ in females [11]. Considering the high mortality rate of CRC (eight percent and nine percent of cases, corresponding to 700,000 estimated deaths/year) [11], together with the associated morbidity, progress in treatment customization [12] and, above all, in primary and secondary prevention, indicates the importance of new insights into CRC etiopathogenesis [13].

Several environmental factors [12] involved in CRC carcinogenesis have been identified: unhealthy behaviors, such as consumption of red meat and alcohol, smoking, reduced physical activity, IBD [14] (comprising Crohn's disease and ulcerative colitis) [15], and certain diseases and conditions, such as type 2 diabetes and obesity, which are related to systemic inflammation [16,17]. Indeed, it has been suggested that systemic inflammation may be critical to the development of CRC 13,16, and may link CRC with obesity, IBD, and periodontitis $[6,7,18]$. In particular, inflammatory mediators, which increase locally and systemically in periodontitis $[10,19]$, together with carcinogens (i.e., nitrosamines), as well as microbial-associated virulence factors from periodontal pathogens, may underlie the association between human CRC and periodontitis.

In addition to environmental factors, genetic susceptibility and/or family history [12] have been recognized as important in ten percent of human CRC cases. The role of genetic factors [20] has been also demonstrated in periodontitis. Therefore, a genetic linkage between periodontitis and CRC has been hypothesized and was investigated in this study.

The primary aim of the present study was to assess, through an experimental investigation performed via computer simulation, the genetic linkages between periodontitis and human colorectal cancer, identifying all the genes involved in such an association, ranking them into cluster in descending order of relevance in such an association, and, finally, pointing out those genes presumed to be "leader" in the association between these disorders. Leader genes, which are considered to be predominant in the genetic determination of complex multi-factorial disorders, or in the genetic linkage between two disorders, as in the association between periodontitis and CRC, may reveal molecular targets for further investigations and focused therapies [20,21].

The secondary aim of the study was to characterize, through a review of current scientific evidence, the main function of leader gene products, their involvement in biological processes, and their role in the onset and progression of CRC and periodontitis, and to determine the putative pathogenic mechanisms associating periodontitis and CRC. Those preliminary data may highlight the possible clinical implications of the genetic linkages between periodontitis and human colorectal cancer and pave the way for targeted molecular experimentations [20,21].

\section{Experimental Section}

The present experimental study, being performed on computer, did not require either ethical approval or informed consent and was concluded on the 3 April 2019.

\subsection{Analysis of the Genetic Linkage between Periodontitis and Human Colorectal Cancer (CRC)}

A bioinformatic method, called leader gene approach [20], was employed to identify genes potentially involved in the association between periodontitis and CRC and especially those presumed to be predominant or "leader" in the genetic linkage between the two disorders.

The multi-step procedure, requiring freely available databases and a specific software program for each of the steps involved, is detailed in Figure 1 and summarized below. 


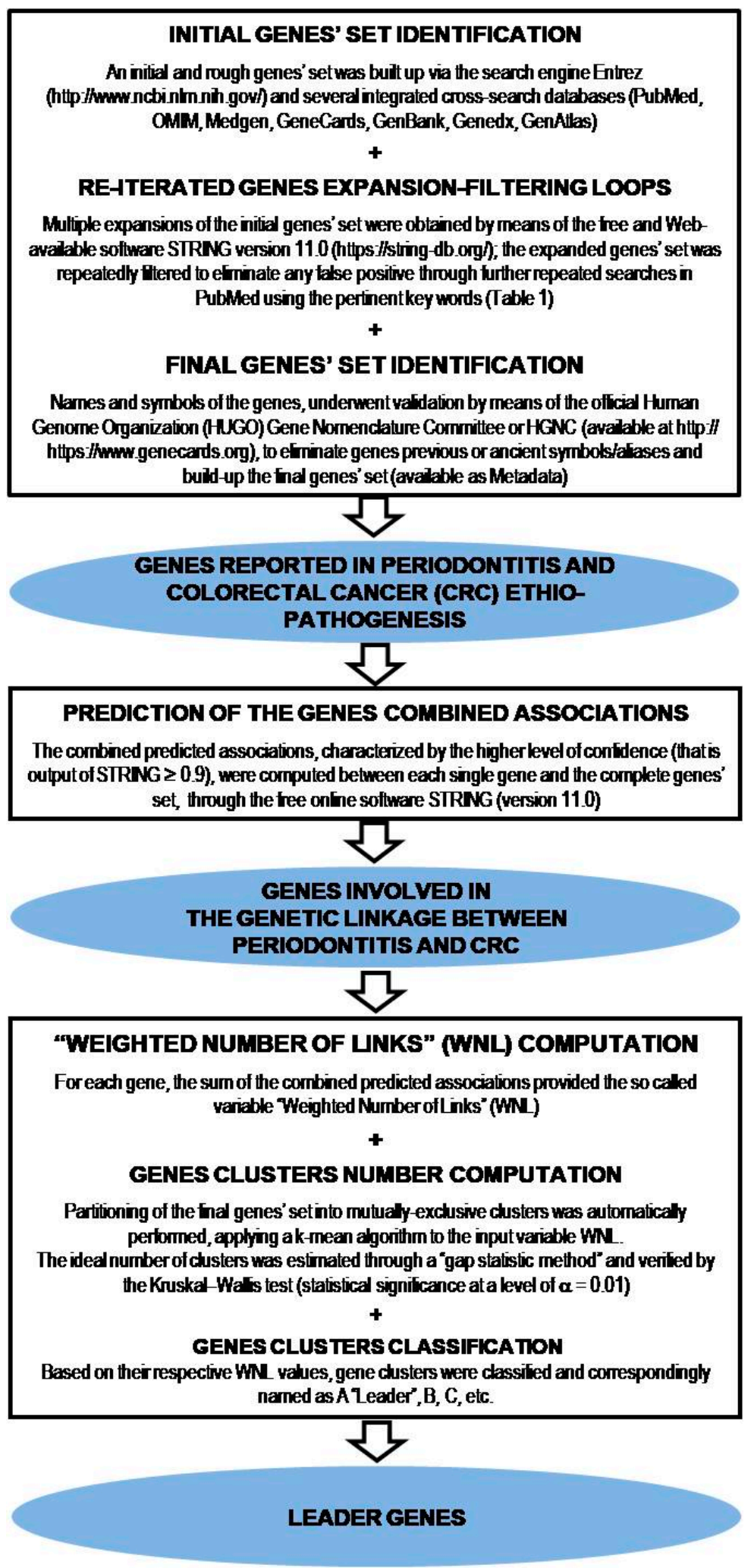

Figure 1. Step by step description of the gene clustering analysis procedure, performed via computer simulation, to investigate the existence of a genetic linkage between periodontitis and human colorectal cancer, and to identify leader genes. 
Preliminarily, an initial set of genes involved in the above-mentioned phenomenon was built up through various integrated cross-search databases (PubMed, OMIM, Medgen, GeneCards, GenBank, Genedx, GenAtlas) using the search engine Entrez (http://www.ncbi.nlm.nih.gov/).

Repeated genes expansions, obtained through the web-available software STRING version 11.0 (https://string-db.org/) ELIXIR infrastructure, Hinxton, UK, and subsequent expanded genes filtrations to eliminate any false positive, through a further search with PubMed, all together defined as "expansion-filtering loops", were performed.

The following key words, achieved by studies investigating either colorectal cancer or periodontitis or both of them [1-20], were employed in the literature search and were logically combined with the Boolean operators AND, OR, NOT.

The name as well as the symbol of each gene, derived by the above-mentioned databases, underwent validation by means of the official Human Genome Organization (HUGO) Gene Nomenclature Committee, or HGNC (available at https://www.genecards.org), in order to eliminate previous symbols or aliases.

The combined predicted associations, characterized by the higher level of confidence (that is a result with a score $\geq 0.9$ ), were computed between each single gene and the complete gene dataset, through the free online software STRING (Version 11.0) [22]. The sum of these combined predicted associations scores provided the so-called the "Weighted Number of Links" (WNL) for each gene.

Automatic computations were performed on the whole data related to the genes included in the study. A k-mean algorithm was applied to the input variable $\mathrm{WNL}$, and a partitioning of the overall dataset of genes into mutually-exclusive clusters was automatically performed and a "gap statistic method" was used to estimate the ideal number of clusters for the clusters from 2 to 12 , as reported in Figure 1. Significant differences among WNLs of cluster groups obtained by the gap statistic method, were found by the Kruskal-Wallis test (statistical significance at a level of $\alpha=0.01$ ), verifying the accurate estimate of the number of clusters.

The resulting gene clusters were classified and correspondingly named as A, B, C, etc., based on their respective value of WNL centroid. The first genes cluster was identified as a "leader" genes cluster, hypothesizing their possible central role in the phenomenon; in contrast, the last genes cluster, identified as "orphans" genes, included genes without identified predicted associations (WNL $=0$ ).

\subsection{Determination of the Putative Pathogenic Mechanisms Associating Periodontitis and CRC}

Leader genes characterization was performed, via the free online software STRING (Version 11.0) [22], to assess the main function of leader gene products and their involvement in biological processes. A further literature search, using the keywords reported in Table 1, was conducted on PubMed/MEDLINE and ScienceDirect search engines (using the same key words reported in Table 1), to investigate the role of leader genes in the onset and in the progression of CRC as well as of periodontitis and to highlight their putative pathogenic mechanisms in the genetic linkage between periodontitis and CRC. 
Table 1. The following key words, achieved by studies investigating either colorectal cancer or periodontitis or both of them $[16,18,19,21,23-41]$, were employed in the literature search and were logically combined with the boolean operators AND, OR, NOT.

\begin{tabular}{lc}
\hline & Key Words \\
\hline$(1)$ & gene AND human \\
\hline$(2)$ & cancer \\
\hline$(3)$ & carcinoma \\
\hline$(4)$ & coR 3 \\
\hline$(5)$ & colon \\
\hline$(6)$ & CRC \\
\hline$(7)$ & 5 OR 6 OR 7 OR 8 \\
\hline$(8)$ & periodontitis \\
\hline$(9)$ & periodontal disease \\
\hline$(10)$ & periodontal inflammation \\
\hline$(11)$ & gingivitis \\
\hline$(12)$ & periodontal disruption \\
\hline$(13)$ & 10 OR 11 OR 12 OR 13 OR 14 \\
\hline$(14)$ & 1 AND 4 AND 9 AND 15 \\
\hline$(15)$ & \\
\hline$(16)$ & \\
\hline
\end{tabular}

\section{Results}

\subsection{Analysis of the Genetic Linkage between Periodontitis and Human Colorectal Cancer}

The final set of genes was composed of 137 genes. A complete description of the identified genes, including acronyms, identification numbers, validated names, cluster assignment, and their involvement in biological processes, is shown in Table A1. In compliance with the estimated optimal number of clusters, shown in Figure 2A, the 137 identified genes were divided into 7 clusters, designated as $A, B, C, D, E, F$, and orphan genes clusters.

WNL computation is reported in Figure 2B. Depending on the WNL score, 54 genes, lacking combined predicted interactions $(\mathrm{WNL}=0)$, were assumed not to be involved in the genetic linkage between periodontitis and CRC, and were, consequently, designated as orphan genes and excluded from the study; the remaining 83 genes, showing a WNL $>0$ and the combined predicted interactions mapped in Figure 2C, were hierarchically grouped in descending order of WNL to the six clusters named from A to F, as illustrated in Figure 3.

In particular, the 12 genes, belonging to cluster $\mathrm{A}$ and defined as leader genes, were: E3 ubiquitin-protein ligase (CBL), catenin beta-1 (CTNNB1), proto-oncogene c-Fos (FOS), growth factor receptor-bound protein 2 (GRB2), interleukins 1B, 4, 6, 10 (IL1B, IL4, IL6, IL10), transcription factor AP-1 (JUN), phosphatidylinositol 4,5-bisphosphate 3-kinase catalytic subunit alpha isoform (PIK3CA), phosphatidylinositol 3-kinase regulatory subunit alpha (PIK3R1), and RELA proto-Oncogene NFKB subunit or transcription factor p65 (RELA).

CBL encodes for an enzyme targeting substrates for proteasomal degradation.

CTNNB1 encodes for $\beta$-catenin, a subunit of the adherens junctions complex, regulating cell growth and adhesion and Wnt responsive genes (i.e., c-Myc) expression, leading to cell cycle progression. 
A

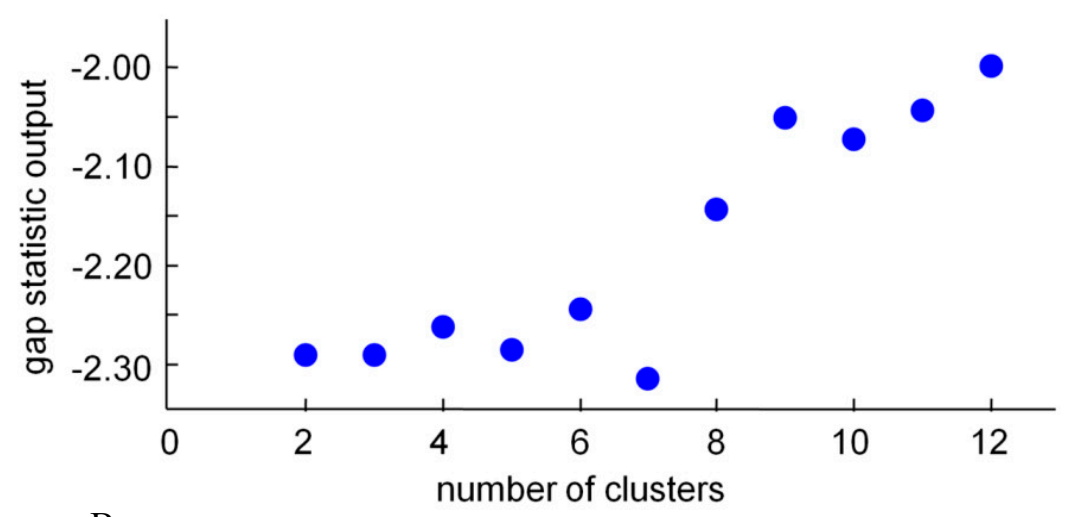

B
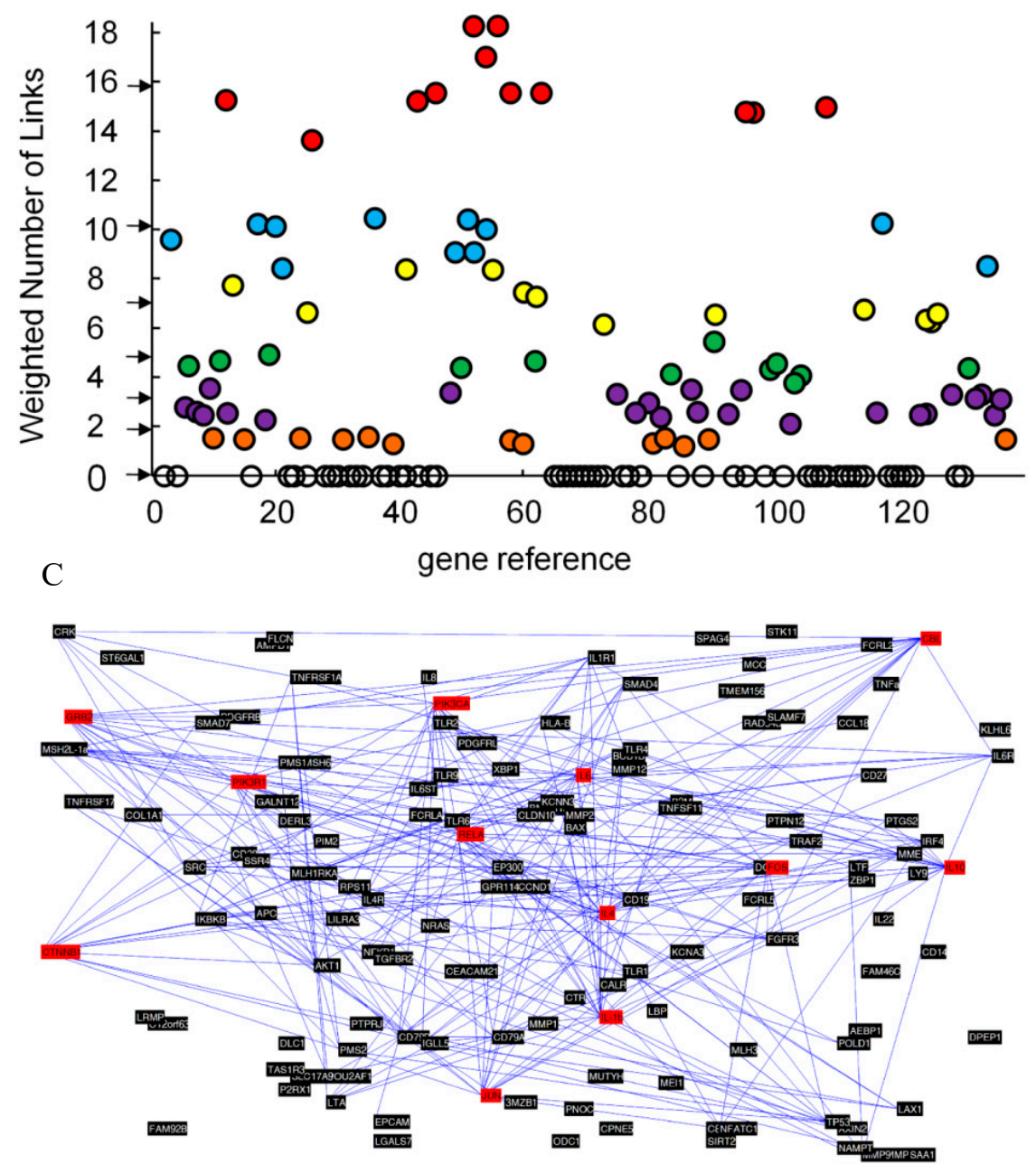

Figure 2. A-C. Data analysis for colorectal cancer and periodontal disease: (A) plot of the gap statistic method for estimating the number of clusters; (B) WNL for genes involved in the phenomenon. Black arrows are the centroids of the cluster groups: leader genes (in red); cluster B genes (in light blue); cluster C genes (in yellow); cluster D genes (in green); cluster E genes (in purple); cluster F genes (in orange); and 'orphan' genes (in clear); (C) final map of interactions of 137 genes involved in the genetic linkage between periodontitis and CRC according to STRING: leader genes are red; the lines that connect single genes represent predicted functional associations among proteins in the confidence view. 


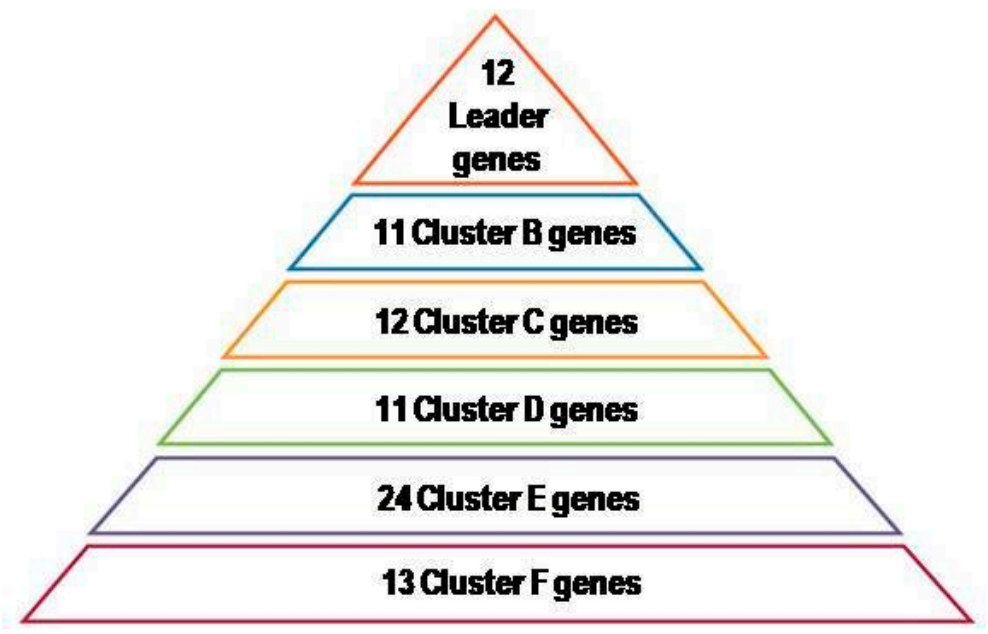

Figure 3. Gene classification in the seven clusters, designated from A to F, based on the number of predicted interactions of genes, excluding the last orphan genes cluster with no predicted interactions.

FOS is an oncogene encoding for the c-Fos protein, which heterodimerizes with c-Jun, encoded by JUN (Transcription factor AP-1), to form the transcription factor AP-1, involved in cell proliferation, differentiation, apoptosis, and cancerous transformation.

GRB2 gene encodes for a protein binding the epidermal growth factor (EGF) receptor, activating several signaling pathways.

IL1B, IL4, IL6, IL10 are active in immune-regulation and inflammation, as discussed below.

PIK3CA and PIK3R1 are centrally involved in several cancers.

RELA (p65), along with NFKB1 (p50), make-up the NFKB complex, which regulates the transcription of several genes encoding for pro-inflammatory cytokines https:/www.genecards. org) [22].

\subsection{Determination of the Putative Pathogenic Mechanisms Associating Periodontitis and CRC}

The characterization of the 12 leader genes in the genetic linkage between periodontitis and human colorectal cancer is reported in Table 2. Identified leader genes were involved in cell signaling (i.e., CTNNB1, CBL, GRB2, PIK3CA, PIK3R1), transcriptional pathways (i.e., JUN, RELA), cell proliferation/differentiation (i.e., FOS), and immuno-inflammatory processes (i.e., IL1B, IL4, IL6, IL10). Current evidence of the role of leader genes in CRC and in periodontitis onset and progression, as well as the putative pathogenic mechanisms is reported in Table 2. 
Table 2. Description of the leader genes identified in the genetic linkage between periodontitis and human colorectal cancer: leader genes product(s) main function', as per the free online software STRING (version 11.0) [22]; role in CRC development and progression; role in periodontitis onset and progression; putative pathogenic mechanisms related to the effects of the products of leader genes.

\begin{tabular}{|c|c|c|c|c|}
\hline Leader Genes & Main Function & Role in CRC & Role in Periodontitis & $\begin{array}{l}\text { Putative Pathogenic } \\
\text { Mechanisms }\end{array}$ \\
\hline CTNNB1 & Cell signaling & $\begin{array}{l}\text { Mutated in up to 90\% of colonic tumors; responsible for initial tissue } \\
\text { dysplastic transformation [22]; encodes for } \beta \text {-catenin, a subunit of the } \\
\text { adherens junctions complex, regulating cell growth and adhesion and Wnt } \\
\text { responsive genes (i.e., c-Myc) expression, leading to cell cycle progression. }\end{array}$ & $\begin{array}{l}\text { Its product, } \beta \text {-catenin, is detectable in periodontal ligament } \\
\text { cell nuclei in mice, potentially influencing periodontal } \\
\text { ligament homeostasis [23]; regulates Wnt responsive genes. } \\
\text { Wnt stimulus induces osteogenic lineage commitment [23], } \\
\text { while Wnt depletion is involved in alveolar bone loss. }\end{array}$ & Cell cycle dysregulation \\
\hline FOS & $\begin{array}{l}\text { Gene(s) transcription, cell } \\
\text { signaling, cell proliferation and } \\
\text { differentiation }\end{array}$ & $\begin{array}{l}\text { rs7101 and rs1063169 FOS single nucleotide polymorphisms are considered } \\
\text { at higher risk of CRC onset [24] and its expression increases in CRC } \\
\text { lesions [25]. In addition, a different member of the FOS family, named } \\
\text { Fra-1, is over-expressed in colonic cancer cells, particularly in those } \\
\text { acquiring motility and invasive ability [25]. Moreover, FOS may participate } \\
\text { in the inflammatory microenvironment associated with CRC [25]. }\end{array}$ & $\begin{array}{l}\text { May be implicated in periodontitis development and } \\
\text { progression through the interaction with } \\
\text { prostaglandin-endoperoxide synthase 2, affecting the T-cell } \\
\text { receptor (TCR) signaling [26]. }\end{array}$ & Cell cycle dysregulation \\
\hline JUN & $\begin{array}{l}\text { Gene(s) transcription, cell } \\
\text { signaling, cell proliferation, and } \\
\text { differentiation inflammation }\end{array}$ & $\begin{array}{l}\text { Its product, c-Jun, heterodimerizes with c-Fos protein, encoded by FOS, to } \\
\text { form the transcription factor AP-1 (see above). Involved in cell } \\
\text { proliferation, differentiation, apoptosis, and malignant } \\
\text { transformation [24,27]. }\end{array}$ & $\begin{array}{l}\text { Its product, c-Jun, heterodimerizes with c-Fos protein, } \\
\text { encoded by FOS, to form the transcription factor AP-1 (see } \\
\text { above). Involved in cell proliferation, differentiation, } \\
\text { apoptosis, and malignant transformation [24,27]. } \\
\text { Its products bind to the epidermal growth factor (EGF) } \\
\text { receptor. }\end{array}$ & Cell cycle dysregulation \\
\hline GRB2 & Cell signaling & $\begin{array}{l}\text { Its products stimulate colonic cell proliferation [28]; in particular, the } \\
\text { Grb2-associated binding protein } 2 \text { (Gab2) has been found responsible for } \\
\text { epithelial mesenchymal transition and consequent CRC metastasis } \\
\text { development [29]. }\end{array}$ & $\begin{array}{l}\text { EGF signaling in the periodontal tissue, indirectly affected } \\
\text { by GRB2 expression, is considered essential in tissue } \\
\text { regeneration; thus, its interruption may affect healing and } \\
\text { regeneration processes. Indeed, EGF ligand alterations, } \\
\text { secondary to the effect of the peptidylarginine deiminase } \\
\text { enzyme, released by porphyromonasgingivalis, interfere } \\
\text { with EGF signaling, and, potentially, favor periodontitis } \\
\text { progression [30]. }\end{array}$ & Cell cycle dysregulation \\
\hline PIK3CA & Cell proliferation, cell survival & $\begin{array}{l}\text { The most frequently mutated gene in breast cancer and is centrally } \\
\text { involved in other malignancies [22]. }\end{array}$ & n.a. & Cell cycle dysregulation \\
\hline PIK3R1 & Cell signaling & Phosphorylated by PIK3CA, it is downregulated in CRC cells [31]. & $\begin{array}{l}\text { It is considered as a marker of severe periodontitis [32]. } \\
\text { Stimulates osteoclastogenesis [34], has been found }\end{array}$ & Cell cycle dysregulation \\
\hline IL6 & Inflammation & $\begin{array}{l}\text { Induces CRC cell growth and invasion; and higher levels of IL6 have been } \\
\text { detected in the serum from CRC patients compared to controls [33]. }\end{array}$ & $\begin{array}{l}\text { associated with chronic as well as aggressive periodontitis } \\
\text { and, together with IL6R, IL6ST, IL4R, and IL1R1 may link } \\
\text { periodontitis to other diseases [20]. }\end{array}$ & $\begin{array}{l}\text { Immuno-inflammatory } \\
\text { response }\end{array}$ \\
\hline IL1B & Immune response & $\begin{array}{l}\text { In CRC cells it is produced in higher concentrations compared to healthy } \\
\text { surrounding tissues, possibly activating the NFKB signaling pathway [35]. }\end{array}$ & $\begin{array}{l}\text { IL1-889 C/T gene polymorphism has been associated with } \\
\text { severe periodontitis [34] and its role in periodontitis } \\
\text { pathogenesis has long been advocated [36]. }\end{array}$ & $\begin{array}{l}\text { Immuno-inflammatory } \\
\text { response }\end{array}$ \\
\hline
\end{tabular}


Table 2. Cont.

\begin{tabular}{|c|c|c|c|c|}
\hline Leader Genes & Main Function & Role in CRC & Role in Periodontitis & $\begin{array}{l}\text { Putative Pathogenic } \\
\text { Mechanisms }\end{array}$ \\
\hline IL4 & Immuno-inflammatory process & $\begin{array}{l}\text { Produced by activated Thelper } 2 \text { lymphocytes, may reduce cancer-directed } \\
\text { response operated by the immune system, encouraging cancer invasion } \\
\text { and metastasis. Through its binding to Type II IL-4 receptor } \alpha \text { (IL-4R } \alpha \text { ) } \\
\text { and JAK/STAT signaling activation, it favors survival of cancer cells and } \\
\text { immunosuppression, so that a dysregulation in II-4 signaling or IL-4R } \alpha \\
\text { gene polymorphisms may be associated with cancer, including CRC [37]. }\end{array}$ & $\begin{array}{l}\text { Plays a protective role in periodontitis progression, } \\
\text { reducing alveolar bone loss. Consequently, IL4 } \\
\text { gingivo-crevicular fluid levels are higher in periodontally } \\
\text { healthy subjects and after non-surgical periodontal } \\
\text { treatment. In addition, the IL4-590 C/T polymorphism has } \\
\text { been reported as potentially associated with an increased } \\
\text { risk of periodontitis development [38]. }\end{array}$ & $\begin{array}{c}\text { Immuno-inflammatory } \\
\text { response }\end{array}$ \\
\hline IL10 & Gene(s) transcription & $\begin{array}{l}\text { Its deficiency favors IBD malignant transformation to } \mathrm{CRC}[4,39] \text {, through } \\
\text { the so called "inflammation-dysplasia-carcinoma sequence", an alternative } \\
\text { to the well-known "adenoma-carcinoma sequence" [2]. }\end{array}$ & $\begin{array}{c}\text { Anti-inflammatory cytokine, down-regulating } \\
\text { monocyte-macrophage response. Its gene polymorphism } \\
\text { has been associated with periodontitis development in } \\
\text { Caucasians [34]. }\end{array}$ & $\begin{array}{c}\text { Immuno-inflammatory } \\
\text { response }\end{array}$ \\
\hline RELA & Cell signaling & $\begin{array}{l}\text { Its expression is higher in malignant compared to healthy colonic cells, } \\
\text { as well as in breast, liver, pancreatic, and gastric cancers, although its role in } \\
\text { cancerogenesis, as well as in periodontitis, is still not fully elucidated [40]. } \\
\text { It may be related to inflammatory bowel disease (IBD) and CRC [41] }\end{array}$ & $\begin{array}{l}\text { It is also classified as leader gene in periodontitis probably } \\
\text { because it is functionally related to NFKB } \\
\text { pro-inflammatory activity [22]. }\end{array}$ & $\begin{array}{c}\text { Immuno-inflammatory } \\
\text { response }\end{array}$ \\
\hline CBL & Cell signaling & $\begin{array}{l}\text { as well as to atherogenesis, and neurodegenerative and autoimmune } \\
\text { diseases, by a de-regulation in the ubiquitin-proteasome system, with } \\
\text { subsequent NFKB activation and immuno-inflammatory response } \\
\text { enhancement. }\end{array}$ & No evidence is available relating CBL to periodontitis [20]. & $\begin{array}{c}\text { Immuno-inflammatory } \\
\text { response }\end{array}$ \\
\hline
\end{tabular}




\section{Discussion}

Periodontitis and human colorectal cancer are complex multi-factorial disorders, dealing with a multitude of genes, which are interconnected by several heterogeneous networks, and whose products are involved in a wide range of biological pathways [20]. In view of this fact, the present experimental investigation of the genetic linkages between periodontitis and CRC was conducted through a bioinformatic method, called "leader gene approach" [20]. This multi-step procedure, as described above, is especially useful in identifying the highest priority genes in the investigated phenomenon $[20,21]$ and provides the necessary synthesis and analysis of the overwhelming amount of raw bioinformatic data generated. Ranking genes hierarchically and identifying leader genes consistently revealed those genes, and their related products, which are mainly involved in the genetic linkage between periodontitis and CRC (Table 2). Such bioinformatic data were subsequently integrated with current evidence to reveal cellular functions and biological processes carried out by the gene products, and were interpreted in view of the available clinical and experimental findings to determine the putative pathogenic mechanisms associating periodontitis with CRC.

\subsection{Genetic Linkages between Periodontitis and Human Colorectal Cancer: Leader Genes and Putative Pathogenic Mechanisms}

Among the 137 genes (complete final gene dataset available as metadata) reported in periodontitis and CRC ethio-pathogenesis, 83 were involved and 12 ("cluster A" or "leader" genes) were considered to play a predominant role in the genetic linkage between both disorders. Notably, four of the cluster A genes, specifically, CBL, GRB2, PIK3R1, and RELA, were also ranked among the five leader genes previously identified in periodontitis [20]. Nuclear factor kappa B p105 subunit (NFKB1), instead, which is considered as a leader gene in periodontitis, was assigned to cluster $C$ in the present study. These results may support the existence of a possible genetic linkage between periodontitis and CRC.

The characterization of the currently identified leader genes, reported in Table 2, revealed their involvement in several biological processes, such as cell signaling (i.e., CTNNB1, CBL, GRB2, PIK3CA, PIK3R1), transcriptional pathways (i.e., JUN, RELA), cell proliferation/differentiation (i.e., FOS) and immuno-inflammatory processes (i.e., IL1B, IL4, IL6, IL10; see Table 2) [22]. Evidence supporting the role exerted by leader genes in both CRC and periodontitis pathogenesis [23-41], reported in Table 2, suggested that the pathogenic mechanisms underlying the association between periodontitis and CRC may be mainly related to the effect of the products of the leader genes on cell cycle dysregulation and on alteration of the immuno-inflammatory response.

Leader genes acting in cell cycle regulation, such as CTNNB1, FOS, JUN, GRB2, PIK3CA, and PIK3R1, may affect homeostasis in both colonic cells and periodontal tissues, causing, if dysregulated, colonic cell proliferation and malignant transformation, on the one hand, and periodontitis development and progression, on the other, as described in Table 2 [22-32].

Leader genes affecting the immune-inflammatory response, such as IL1B, IL4, IL6, IL10, CBL, and RELA, may underlie a possible bi-directional relationship between the disorders, as described below [20,33-40]. Moreover, in addition to leader genes affecting the immune-inflammatory response, $N F K B$, which has been ranked among cluster $C$ genes and is functionally related to RELA, regulates the transcription of several genes, also encoding for pro-inflammatory cytokines. NFKB is constitutively inactivated and its activation, with subsequent immuno-inflammatory response alteration, may be due to a dysregulation in the ubiquitin-proteasome system, which is a mechanism of intracellular protein degradation, occurring in atherogenesis, neurodegenerative and autoimmune diseases, and, possibly, in IBD and CRC [41,42]. Current knowledge about the role of the cellular ubiquitin-proteasome system dysregulation, and subsequent NFKB activation in periodontitis, is still limited, but it may explain the presence of the $\mathrm{E} 3$ ubiquitin-protein ligase (CBL) gene among the leader genes in the genetic linkage between periodontitis and CRC, although no evidence is available relating CBL to periodontitis [20]. 


\subsection{Genetic Linkages between Periodontitis and Human Colorectal Cancer: Cytokines and Systemic Inflammation}

Periodontal tissue destruction, occurring in periodontitis, is microbially initiated and sustained by the dysregulation of the immune-inflammatory processes [5]. A body of evidence has shown that cytokines produced in inflamed periodontal tissues, together with virulence factors from periodontal pathogens and oral microbial agents, may gain access to the circulation, and, consequently, induce systemic inflammation [5,43]. Accordingly, it has been proposed that non-resolving periodontal inflammation may affect systemic inflammatory diseases and that cytokines may be considered as a possible pathogenic link between periodontitis and various systemic diseases, including IBD and CRC $[4-7,38,44]$.

It is well known that IBD has oral mucosal manifestations, such as pyostomatitis vegetans and aphthous stomatitis, and it has been reported that subjects suffering from Crohn's disease show a higher risk of periodontitis compared to non-IBD subjects [8,45]. In addition, evidence suggests that periodontal pathogens, especially Fusobacterium nucleatum, may be involved in IBD $[9,10]$ and colorectal adenomas [46], and that cytokines induced by periodontal pathogens and released in periodontitis may predispose to neoplastic transformation of chronic colitis, favoring colorectal carcinogenesis $[12,46,47]$. In more detail, oral fusobacterium nucleatum, which is abundant in the oral cavity and increased in periodontal pockets, is mobile and caplable to bind, through the Fusobacterium adhesin $\mathrm{A}(\mathrm{FadA})$, both to vascular endothelial-cadherins, gaining access to systemic circulation, and to (E)-cadherin on epithelial cells, stimulating the growth of tumor cells. Binding to (E)-cadherins on colorectal adenoma and cancer cells, FadA, which is only detectable on oral Fusobacterium species, activates the transcriptions of those oncogenes regulated by b-catenin, which is the product of the leader gene CTNNB1, and of some genes involved into the immune-inflammatory response, including IL6, which is presently ranked as a leader gene, and NFKB, belonging to cluster C genes [46]. From this standpoint, periodontitis may be considered as a possible risk factor for CRC genesis in IBD subjects, as it accounts for poor metabolic control in diabetic patients [48]. Such an inter-relationship may rely on the fact that both IBD and periodontitis share a multifactorial etiology, as well as the pathogenic mechanisms affecting the local immuno-inflammatory response, which leads to the genesis of a systemic inflammation [45]. Analogously, it may be supposed that those periodontal cytokines, which are listed among leader genes products, may enhance colonic tumor-associated inflammation, and may subsequently be considered as a risk factor for cancer progression in CRC subjects. As a counterpart, along with the tumor-associated inflammatory environment, CRC cells themselves release inflammatory mediators, which self-sustain neoplastic cell growth and enhance the cancerous cells' interactions with the surrounding stroma and immune cells, favoring, in turn, CRC progression and invasion [13,49]. Since CRC inflammatory mediators have been identified as leader genes in the present study, it may be hypothesized, as previously proposed for cytokines released in diabetes [43], that CRC cytokines may negatively affect periodontitis onset and development, altering the immune-inflammatory response in periodontal tissues.

\subsection{Genetic Linkages between Periodontitis and Human Colorectal Cancer: Possible Clinical Implications}

The findings discussed, certainly requiring validation by larger studies, may provide preliminary data for further research, especially considering the beneficial clinical applications potentially offered by the insight into the mechanisms associating periodontitis and CRC. Indeed, if the results presented, which suggest a central role for cytokines and systemic inflammation in the genetic bi-directional linkage between periodontitis and CRC, are validated, periodontitis management may be included in CRC prevention and treatment plans. Complex multi-factorial disorders, such as periodontitis and CRC, significantly impact on the quality of life, present life-threatening risks, and imply a heavy burden on society. Therefore, highlighting the genetic traits of such disorders may pave the way for primary prevention strategies, which are essential to reduce the biological impact as well as the healthcare costs of these disorders. The improved understanding of the putative pathogenic mechanisms associating 
periodontitis with CRC may encourage a multidisciplinary approach, which is strongly advocated for such complex multifactorial disorders.

From this standpoint, oral health professionals may also become part of CRC screening plans, introducing, in their daily practice, general health promotion and disease prevention goals, and including risk assessment for both oral and systemic diseases. CRC screening might be improved by the provision of broader dental health records, with the potential to identify subjects at risk for CRC development for referral to a physician. In addition, based on the definition of oral health as a component of general health affecting the quality of life [50], oral health professionals may widen their activity in an interprofessional setting, providing oral and periodontal evaluation and necessary treatments, in CRC subjects referred by other health professionals, integrating the patient's medical care in therapeutic and follow-up plans.

Periodontal treatment may be proposed as a CRC primary prevention strategy, in subjects considered at higher risk for CRC development, such as those suffering from IBD, in order to decrease the systemic inflammation and the related pro-carcinogenic environment. However, threshold values of cytokines in inflamed periodontal tissues, capable of inducing systemic inflammation and subsequently increasing the risk for colorectal cancer genesis, in IBD subjects have not yet been defined. Furthermore, the quantitative assessment of periodontal cytokines is even more complicated than the qualitative one, since it may actually be biased by the accidental detection of inflammatory mediators possibly derived from mucosal inflammation and orally administered drugs, in whole saliva analysis, and by the need for full mouth sampling, in gingival crevicular fluid analysis [51]. For these reasons, identifying those IBD subjects potentially exposed to a higher risk of systemic inflammation induced by periodontitis, and of consequent malignant transformation of chronic colitis, may be impracticable. Thus, periodontitis prevention and treatment, which potentially reduces systemic inflammation and, consequently, decreases the risk for malignant transformation of chronic colitis, may be routinely included in all IBD subjects' treatment plans. Moreover, periodontal treatment, reducing the periodontal microbial load and the related cytokine levels, may decrease the systemic spread of inflammatory mediators and of Fusobacterium nucleatum, specifically, presumed to be associated with CRC, beyond IBD, lesions [41,46], and to favor tumor-associated environment, and may, therefore, constitute a secondary and/or tertiary prevention strategy in subjects affected by CRC.

\section{Conclusions}

Four out of the five leader genes previously identified for periodontitis (CBL, GRB2, PIK3R1, and RELA) were also listed as leader genes in the investigated phenomenon, carefully supporting the genetic linkages between CRC and periodontitis, and suggesting the need for a multi-disciplinary approach, also involving oral health professionals, to CRC subject management.

IL1B, IL4, IL6, IL10 were also ranked among leader genes, suggesting a central role for systemic inflammation in the genomic relationship between CRC and periodontitis; in particular, periodontitis may be linked to IBD, and, in turn, to CRC, both affecting the inflammatory pro-carcinogenic and tumor-associated environment and acting in an indirect way in the "inflammation-dysplasia" carcinogenic sequence, favoring colorectal cancer development. In this perspective, periodontitis management may be proposed as a CRC primary prevention strategy, especially in patients considered at higher risk for CRC development, such as IBD subjects. Indeed, periodontal therapy would reduce the periodontal microbial charge, and, consequently, the systemic widespread of bacterial toxins and of periodontal pathogens them-selves, including Porphyromonas gingivalis and Fusobacterium nucleatum, supposed to be associated with IBD and CRC lesions. Moreover, periodontal treatment and healthy periodontal conditions would indirectly decrease the systemic inflammation and the related CRC pro-carcinogenic environment, as a part of the CRC treatment strategy. 
Author Contributions: Conceptualization, F.D.S., P.T., V.P., and L.S.; methodology, F.D.S., P.T., V.P., and L.S.; software, P.T.; validation, X.X., Y.Y., and Z.Z.; formal analysis, P.T.; investigation, F.D.S. and P.T.; resources, F.D.S.; data curation, F.D.S., P.T., V.P., F.C., D.L., and L.S.; writing-original draft preparation, F.D.S., P.T., and L.S.; writing-review and editing, F.D.S., P.T., V.P., F.C., D.L., and L.S.; visualization, X.X.; supervision, X.X.; project administration, X.X.; funding acquisition, Y.Y. All authors have read and agreed to the published version of the manuscript.

Funding: This research received no external funding.

Conflicts of Interest: The authors declare no conflicts of interest.

\section{Appendix A}

Table A1. Identified genes acronyms, identification numbers, validated names, cluster assignment, and biological process(es) involvement description, as per the free online software STRING (version 11.0) [22].

\begin{tabular}{|c|c|c|c|c|}
\hline Gene Acronym & $\begin{array}{c}\text { Gene } \\
\text { Identification } \\
\text { Number }\end{array}$ & Gene Official Name & $\begin{array}{l}\text { Protein Main Function/Biological } \\
\text { Process (Es) Involvement }\end{array}$ & $\begin{array}{l}\text { Gene Cluster } \\
\text { Assignment }\end{array}$ \\
\hline CBL & 12 & E3 ubiquitin-protein ligase CBL & Cell signaling & A \\
\hline CTNNB1 & 26 & Catenin beta- 1 & Cell signaling & A \\
\hline FOS & 43 & Proto-oncogene c-Fos & $\begin{array}{l}\text { Gene (s) transcription, cell signaling, cell } \\
\text { proliferation, and differentiation }\end{array}$ & A \\
\hline GRB2 & 46 & $\begin{array}{c}\text { Epidermal Growth Factor Receptor-Binding } \\
\text { Protein GRB2 }\end{array}$ & Cell signaling & A \\
\hline IL1B & 52 & Interleukin 1 beta & Inflammation & A \\
\hline IL4 & 54 & Interleukin 4 & Immune response & $\mathrm{A}$ \\
\hline IL6 & 56 & Interleukin 6 & Immuno-inflammatory process & A \\
\hline IL10 & 58 & Interleukin 10 & Inflammation & A \\
\hline JUN & 63 & Transcription factor AP-1 & Gene(s) transcription & $\mathrm{A}$ \\
\hline PIK3CA & 96 & $\begin{array}{l}\text { Phosphatidylinositol 4,5-bisphosphate } \\
\text { 3-kinase catalytic subunit alpha isoform }\end{array}$ & Cell proliferation, cell survival & A \\
\hline PIK3R1 & 97 & $\begin{array}{c}\text { Phosphatidylinositol 3-kinase regulatory } \\
\text { subunit alpha }\end{array}$ & Cell signaling & A \\
\hline RELA & 109 & $\begin{array}{l}\text { RELA Proto-Oncogene, NF-KB Subunit or } \\
\text { Transcription factor p } 65\end{array}$ & $\begin{array}{l}\text { Sub-unit of the transcription factor } \\
\text { NF-kappa-B }\end{array}$ & A \\
\hline AKT1 & 2 & RAC-alpha serine/threonine-protein kinase & $\begin{array}{l}\text { Cell proliferation, cell survival, } \\
\text { angiogenesis }\end{array}$ & B \\
\hline CD19 & 16 & B-lymphocyte antigen CD19 & Immune response & B \\
\hline CD79A & 19 & $\begin{array}{l}\text { B-cell antigen receptor complex-associated } \\
\text { protein alpha chain }\end{array}$ & Immune response & B \\
\hline CD79B & 20 & $\begin{array}{l}\text { B-cell antigen receptor complex-associated } \\
\text { protein beta chain }\end{array}$ & Immune response & B \\
\hline EP300 & 35 & Histone acetyl transferase p300 & $\begin{array}{l}\text { Regulates genes transcription via } \\
\text { chromatin remodeling }\end{array}$ & B \\
\hline IGLL5 & 48 & Immunoglobulin lambda like polypeptide 5 & $\begin{array}{l}\text { Associated with solitary osseous } \\
\text { plasmacytoma }\end{array}$ & B \\
\hline IKBKB & 50 & $\begin{array}{l}\text { Inhibitor of nuclear factor kappa-B kinase } \\
\text { subunit beta }\end{array}$ & Cell signaling (NF- kappa-B pathway) & B \\
\hline IL-1a & 51 & Interleukin-1 alpha & Immuno-inflammatory process & B \\
\hline IL1R1 & 53 & Interleukin-1 receptor type 1 & Cell signaling & B \\
\hline SRC & 117 & Proto-oncogene tyrosine-protein kinase Src & $\begin{array}{l}\text { Gene(s) transcription, immune response, } \\
\text { cell cycle regulation, cell adhesion, and } \\
\text { migration }\end{array}$ & B \\
\hline TP53 & 134 & Cellular tumor antigen p53 & Cell cycle regulation & B \\
\hline CCND1 & 13 & G1/S-specific cyclin-D & Cell cycle regulation & $\mathrm{C}$ \\
\hline CRK & 25 & Adapter molecule crk & $\begin{array}{l}\text { Phagocytosis of apoptotic cells, cell } \\
\text { motility }\end{array}$ & $\mathrm{C}$ \\
\hline FGFR3 & 41 & Fibroblast growth factor receptor 3 & $\begin{array}{l}\text { Cell proliferation, differentiation, and } \\
\text { apoptosis, and skeleton development }\end{array}$ & $\mathrm{C}$ \\
\hline IL4R & 55 & Interleukin-4 receptor subunit alpha & Immune response & $\mathrm{C}$ \\
\hline IL6R & 60 & Interleukin-6 receptor subunit alpha & Immuno-inflammatory process & C \\
\hline IRF4 & 62 & Interferon regulatory factor 4 & $\begin{array}{l}\text { Immune response, dendritic cell } \\
\text { differentiation }\end{array}$ & C \\
\hline LTA & 73 & Lymphotoxin-alpha & Immune response & C \\
\hline NFKB1 & 91 & Nuclear factor NF-kappa-B p105 subunit & $\begin{array}{l}\text { Cell signaling, immuno-inflammatory } \\
\text { process, cell cycle regulation, and } \\
\text { differentiation, tumorigenesis }\end{array}$ & C \\
\hline SMAD4 & 115 & Mothers against decapentaplegic homolog 4 & Muscle physiology & C \\
\hline TLR2 & 125 & Toll-like receptor 2 & Immune response & $\mathrm{C}$ \\
\hline TLR4 & 126 & Toll-like receptor 4 & Immune response & $\mathrm{C}$ \\
\hline TLR6 & 127 & Toll-like receptor 6 & Immune response & $\mathrm{C}$ \\
\hline AURKA & 5 & Aurora kinase A & Cell cycle regulation & $\mathrm{D}$ \\
\hline $\mathrm{B} 2 \mathrm{M}$ & 10 & Beta-2-microglobulin & Immune response & $\mathrm{D}$ \\
\hline CD38 & 18 & $\begin{array}{l}\text { ADP-ribosylcyclase/cyclic } \\
\text { ADP-ribosehydrolase } 1\end{array}$ & $\begin{array}{l}\text { Synthesizes the second messengers cyclic } \\
\text { ADP-ribose and nicotinate-adenine } \\
\text { dinucleotide phosphate }\end{array}$ & $\mathrm{D}$ \\
\hline
\end{tabular}


Table A1. Cont.

\begin{tabular}{|c|c|c|c|c|}
\hline Gene Acronym & $\begin{array}{l}\text { Gene } \\
\text { Identification } \\
\text { Number }\end{array}$ & Gene Official Name & $\begin{array}{l}\text { Protein Main Function/Biological } \\
\text { Process (Es) Involvement }\end{array}$ & $\begin{array}{l}\text { Gene Cluster } \\
\text { Assignment }\end{array}$ \\
\hline IGJ & 49 & Immunoglobulin J chain & Immune response & $\mathrm{D}$ \\
\hline IL6ST & 61 & Interleukin- 6 receptor subunit beta & $\begin{array}{l}\text { Cell signaling, immune response, } \\
\text { hematopoiesis, pain control, bone } \\
\text { metabolism }\end{array}$ & $\mathrm{D}$ \\
\hline MMP9 & 83 & Matrix metalloproteinase- 9 & $\begin{array}{l}\text { Extracellular matrix degradation, } \\
\text { leukocyte migration, bone osteoclastic } \\
\text { resorption }\end{array}$ & $\mathrm{D}$ \\
\hline NFATC1 & 90 & $\begin{array}{l}\text { Nuclear factor of activated T-cells, } \\
\text { cytoplasmic } 1\end{array}$ & $\begin{array}{c}\text { Immuno-inflammatory process, } \\
\text { osteoclastogenesis }\end{array}$ & $\mathrm{D}$ \\
\hline PMS1 & 99 & PMS1 protein homolog 1 & DNA repair & $\mathrm{D}$ \\
\hline PMS2 & 100 & Mismatch repair endonuclease PMS2 & DNA repair & $\mathrm{D}$ \\
\hline POU2AF1 & 103 & POU domain class 2-associating factor & Immune response & $\mathrm{D}$ \\
\hline PTGS2 & 104 & Prostaglandin $\mathrm{G} / \mathrm{H}$ synthase 2 & Inflammation & $\mathrm{D}$ \\
\hline TNFRSF1A & 131 & $\begin{array}{l}\text { Tumor necrosis factor receptor superfamily } \\
\text { member } 1 \mathrm{~A}\end{array}$ & (Pro) Apoptosis & $\mathrm{D}$ \\
\hline APC & 4 & Adenomatous polyposis coli protein & Tumor suppressor (Wnt pathway) & E \\
\hline AXIN2 & 6 & Axin-2 & Cell signaling (Wnt pathway) & E \\
\hline $\mathrm{BAX}$ & 7 & Apoptosis regulator BAX & (Pro) Apoptosis & E \\
\hline BMPR1A & 8 & $\begin{array}{c}\text { Bone morphogenetic protein receptor } \\
\text { type- } 1 \mathrm{~A}\end{array}$ & $\begin{array}{l}\text { Chondrocyte differentiation, } \\
\text { Adipogenesis }\end{array}$ & E \\
\hline CALR & 11 & Calreticulin & Cell endoplasmic reticulum formation & E \\
\hline $\mathrm{CD} 27$ & 17 & CD27 antigen & Immune response & E \\
\hline HLA-B & 47 & $\begin{array}{l}\text { HLA class I histocompatibility antigen, B-7 } \\
\text { alpha chain }\end{array}$ & Immune response & E \\
\hline LTF & 74 & Lactotransferrin & $\begin{array}{l}\text { Immuno-inflammatory process, } \\
\text { protection against cancer development } \\
\text { and metastasis }\end{array}$ & E \\
\hline MLH1 & 77 & DNA mismatch repair protein Mlh1 & DNA repair & E \\
\hline MME & 79 & Neprilysin & $\begin{array}{l}\text { Opioid peptides, angiotensin- }-2,-1,-9 \text { and } \\
\text { atrial natriuretic factor degradation }\end{array}$ & E \\
\hline MMP2 & 81 & Matrix metalloproteinase-2 & $\begin{array}{l}\text { Inflammation, tissue repair, angiogenesis, } \\
\text { tumor invasion }\end{array}$ & E \\
\hline MSH2 & 86 & DNA mismatch repair protein Msh2 & DNA repair & E \\
\hline MSH6 & 87 & DNA mismatch repair protein Msh6 & DNA repair & E \\
\hline NRAS & 96 & GTPase NRas & $\begin{array}{l}\text { Binds GDP/GTP and possesses intrinsic } \\
\text { GTPase activity }\end{array}$ & E \\
\hline PDGFRB & 94 & Platelet-derived growth factor receptor beta & $\begin{array}{l}\text { Tyrosine-protein kinase acting as } \\
\text { cell-surface receptor, playing an essential } \\
\text { role in blood vessel development }\end{array}$ & E \\
\hline POLD1 & 102 & DNA Polymerase Delta 1 Catalytic Subunit & $\begin{array}{l}\text { Plays a crucial role in high fidelity } \\
\text { genome replication, requiring the } \\
\text { presence of accessory proteins POLD2, } \\
\text { POLD3, and POLD4 for full activity }\end{array}$ & E \\
\hline SMAD7 & 116 & Mothers against decapentaplegic homolog 7 & TGF-beta inhibition & E \\
\hline TGFBR2 & 123 & TGF-beta receptor type-2 & $\begin{array}{l}\text { Cell cycle regulation (epithelial and } \\
\text { hematopoietic cells), cell proliferation and } \\
\text { differentiation (mesenchymal cells) } \\
\text { Immune response }\end{array}$ & E \\
\hline TLR1 & 124 & Toll-like receptor 1 & Immune response & E \\
\hline TLR9 & 128 & Toll-like receptor 9 & Immune response & E \\
\hline TNFRSF17 & 132 & $\begin{array}{l}\text { Tumor necrosis factor receptor superfamily } \\
\text { member } 17\end{array}$ & Immune response & E \\
\hline TNFSF11 & 133 & $\begin{array}{l}\text { Tumor necrosis factor ligand superfamily } \\
\text { member } 11\end{array}$ & Immune response & E \\
\hline TRAF2 & 135 & TNF receptor-associated factor 2 & $\begin{array}{l}\text { NF-kappa-B and JNK activation, cell } \\
\text { survival and apoptosis regulation, } \\
\text { immune response }\end{array}$ & E \\
\hline XBP1 & 136 & X-box-binding protein 1 & $\begin{array}{c}\text { Cardiac, hepatic, and secretory tissue } \\
\text { development }\end{array}$ & E \\
\hline BUB1B & 9 & $\begin{array}{l}\text { Mitotic checkpoint serine/threonine-protein } \\
\text { kinase BUB1 beta }\end{array}$ & Cell cycle regulation & $\mathrm{F}$ \\
\hline CCL18 & 14 & C-C motif chemokine 18 & Immune response & $\mathrm{F}$ \\
\hline COL1A1 & 23 & Collagen alpha-1 (I) chain & Member of group I collagen & F \\
\hline DCC & 30 & Netrin receptor DCC & Nervous system development & $\mathrm{F}$ \\
\hline EPCAM & 34 & EPCAM Epithelial cell adhesion molecule & Immune response & $\mathrm{F}$ \\
\hline FCRLA & 38 & Fc receptor-like A & Immune response & $\mathrm{F}$ \\
\hline IL8 & 57 & Interleukin-8 & Immune response & F \\
\hline IL22 & 59 & Interleukin-22 & Inflammation & F \\
\hline MMP1 & 80 & Matrix metalloproteinase- 1 & $\begin{array}{l}\text { Types I, II, III, VII, and X collagens } \\
\text { degradation }\end{array}$ & F \\
\hline MMP7 & 82 & Matrix metalloproteinase-7 & $\begin{array}{l}\text { Casein, type I, III, IV, and V gelatins and } \\
\text { fibronectin degradation }\end{array}$ & F \\
\hline MZB1 & 85 & Marginal zone B- and B1-cell-specific protein & Immune response & F \\
\hline NAMPT & 89 & Nicotinamide phosphoribosyl transferase & Immune response, anti-diabetic function & $\mathrm{F}$ \\
\hline ZBP1 & 137 & Z-DNA-bindin gprotein 1 & Immune response & $\mathrm{F}$ \\
\hline
\end{tabular}


Table A1. Cont.

\begin{tabular}{|c|c|c|c|c|}
\hline Gene Acronym & $\begin{array}{c}\text { Gene } \\
\text { Identification } \\
\text { Number }\end{array}$ & Gene Official Name & $\begin{array}{l}\text { Protein Main Function/Biological } \\
\text { Process (Es) Involvement }\end{array}$ & $\begin{array}{c}\text { Gene Cluster } \\
\text { Assignment }\end{array}$ \\
\hline AEBP1 & 1 & Adipocyte enhancer-binding protein 1 & $\begin{array}{l}\text { Adipocyte proliferation, enhanced } \\
\text { macrophage inflammatory } \\
\text { responsiveness }\end{array}$ & Orphan \\
\hline AMPD1 & 3 & AMP deaminase 1 & Energy metabolism & Orphan \\
\hline CD14 & 15 & Monocyte differentiation antigen CD14 & Immune response & Orphan \\
\hline CEACAM21 & 21 & $\begin{array}{c}\text { Carcinoembryonic Antigen Related Cell } \\
\text { Adhesion Molecule } 21\end{array}$ & Immune response & Orphan \\
\hline CLDN10 & 22 & Claudin-10 & Cell adhesion & Orphan \\
\hline CPNE5 & 24 & Copine-5 & Melanocytes formation & Orphan \\
\hline CTR & 27 & Calcitonin receptor & Receptor for calcitonin & Orphan \\
\hline C12orf63 & 28 & Cilia- and flagella-associated protein 54 & Cilia and flagella assembly & Orphan \\
\hline C8orf80 & 29 & $\begin{array}{c}\text { Nuclear GTPase, Germinal Center } \\
\text { Associated }\end{array}$ & Genome stability & Orphan \\
\hline DERL3 & 31 & Derlin-3 & $\begin{array}{l}\text { Endoplasmic reticulum stress-induced } \\
\text { pre-emptive quality control }\end{array}$ & Orphan \\
\hline DLC1 & 32 & Rho GTPase-activating protein 7 & Cell proliferation and migration & Orphan \\
\hline DPEP1 & 33 & Dipeptidase 1 & Immuno-inflammatory process & Orphan \\
\hline FAM46C & 36 & Nucleotidyl transferase FAM46C & RNA polymerization & Orphan \\
\hline FAM92B & 37 & Protein FAM92B & Ciliogenesis & Orphan \\
\hline FCRL2 & 39 & Fc receptor-like protein 2 & Immune response, B-cells tumorigenesis & Orphan \\
\hline FCRL5 & 40 & Fc receptor-like protein 5 & Immune response & Orphan \\
\hline FLCN & 42 & Folliculin & Tumor suppression & Orphan \\
\hline GALNT12 & 44 & $\begin{array}{l}\text { Polypeptide } \mathrm{N} \text {-acetylgalactosaminyl } \\
\text { transferase } 12\end{array}$ & Oligosaccharide biosynthesis & Orphan \\
\hline GPR114 & 45 & Adhesion G-protein coupled receptor G5 & Cell signaling & Orphan \\
\hline KCNA3 & 64 & $\begin{array}{l}\text { Potassium voltage-gated channel subfamily } \\
\text { A member } 3\end{array}$ & $\begin{array}{l}\text { Mediates the voltage-dependent } \\
\text { potassium ion permeability of excitable } \\
\text { membranes }\end{array}$ & Orphan \\
\hline KCNN3 & 65 & $\begin{array}{l}\text { Small conductance calcium-activated } \\
\text { potassium channel protein } 3\end{array}$ & $\begin{array}{l}\text { Forms a voltage-independent potassium } \\
\text { channel activated by intracellular calcium }\end{array}$ & Orphan \\
\hline KLHL6 & 66 & Kelch-like protein 6 & Immune response & Orphan \\
\hline LAX1 & 67 & Lymphocyte trans membrane adapter 1 & Immune response & Orphan \\
\hline LBP & 68 & Lipopolysaccharide-binding protein & Immune response & Orphan \\
\hline LGALS7 & 69 & Galectin-7 & Cell growth control & Orphan \\
\hline LILRA3 & 70 & $\begin{array}{l}\text { Leukocyte Immunoglobulin Like Receptor } \\
\text { A3 }\end{array}$ & Immune response & Orphan \\
\hline LY9 & 71 & T-lymphocyte surface antigen Ly-9 & Immune response & Orphan \\
\hline LRMP & 72 & Lymphoid-restricted membrane protein & Immune response & Orphan \\
\hline $\mathrm{MCC}$ & 75 & Colorectal mutant cancer protein & Tumor suppression & Orphan \\
\hline MEI1 & 76 & Meiosis inhibitor protein 1 & Meiosis & Orphan \\
\hline MLH3 & 78 & DNA mismatch repair protein Mlh3 & DNA repair & Orphan \\
\hline MMP12 & 84 & Macrophage metalloelastase & Tissue remodeling & Orphan \\
\hline MUTYH & 88 & Adenine DNA glycosylase & DNA repair & Orphan \\
\hline ODC1 & 93 & Ornithine decarboxylase & $\begin{array}{l}\text { DNA replication, cell proliferation, and } \\
\text { apoptosis }\end{array}$ & Orphan \\
\hline PDGFRL & 95 & $\begin{array}{l}\text { Platelet-derived growth factor receptor-like } \\
\text { protein }\end{array}$ & $\begin{array}{l}\text { Associated with colorectal cancer and } \\
\text { other malignancies }\end{array}$ & Orphan \\
\hline PIM2 & 98 & Serine/threonine-protein kinase pim-2 & Cell proliferation, cell survival & Orphan \\
\hline PNOC & 107 & Prepronociceptin & Nociception, neuronal development & Orphan \\
\hline PTPN12 & 105 & $\begin{array}{l}\text { Tyrosine-protein phosphatase non-receptor } \\
\text { type } 12\end{array}$ & Cell signaling & Orphan \\
\hline PTPRJ & 106 & $\begin{array}{l}\text { Receptor-type tyrosine-protein phosphatase } \\
\text { eta }\end{array}$ & $\begin{array}{l}\text { Cell proliferation and differentiation, cell } \\
\text { adhesion and migration, platelet } \\
\text { activation, and thrombosis }\end{array}$ & Orphan \\
\hline $\mathrm{P} 2 \mathrm{R} X 1$ & 107 & P2X purinoceptor 1 & Synaptic transmission & Orphan \\
\hline RAD54B & 108 & $\begin{array}{l}\text { DNA repair and recombination protein } \\
\text { RAD54B }\end{array}$ & DNA repair & Orphan \\
\hline RPS11 & 110 & Ribosomal protein S11 & $40 \mathrm{~S}$ sub-unit ribosomal protein & Orphan \\
\hline SAA1 & 111 & Serumamyloid A-1 protein & Inflammation & Orphan \\
\hline SIRT2 & 112 & $\begin{array}{l}\text { NAD-dependent protein deacetylase } \\
\text { sirtuin-2 }\end{array}$ & Cell cycle regulation & Orphan \\
\hline SLAMF7 & 113 & SLAM family member 7 & Immune response & Orphan \\
\hline SLC17A9 & 114 & Solute carrier family 17 member 9 & ATP storage and exocytosis & Orphan \\
\hline SPAG & 118 & RNA polymerase II-associated protein 3 & RNA polymerization & Orphan \\
\hline SSR4 & 119 & Translocon-associated protein subunit delta & $\begin{array}{l}\text { Retention of ER resident proteins } \\
\text { regulation }\end{array}$ & Orphan \\
\hline STK11 & 120 & Serine/threonine-protein kinase STK11 & Tumor suppression & Orphan \\
\hline ST6GAL1 & 121 & Beta-galactoside alpha-2,6-sialyltransferase 1 & $\begin{array}{c}\text { Transfers sialic acid from CMP-sialic acid } \\
\text { to galactose-containing acceptor } \\
\text { substrates }\end{array}$ & Orphan \\
\hline TAS1R3 & 122 & Taste receptor type 1 member 3 & Umami taste stimulus response & Orphan \\
\hline TMEM156 & 129 & Transmembrane protein 156 & Transmembrane protein & Orphan \\
\hline TNFa & 130 & Tumor necrosis factor & $\begin{array}{l}\text { Cell proliferation and differentiation, } \\
\text { tumor cells death }\end{array}$ & Orphan \\
\hline
\end{tabular}




\section{References}

1. Tonetti, M.S.; Greenwell, H.; Kornman, K.S. Staging and grading of periodontitis: Framework and proposal of a new classification and case definition. J. Periodontol. 2018, 89, 159-172. [CrossRef]

2. Lang, N.P.; Bartold, P.M. Periodontal health. J. Periodontol. 2018, 89, 9-16. [CrossRef]

3. Sbordone, L.; Sbordone, C.; Filice, N.; Menchini-Fabris, G.; Baldoni, M.; Toti, P. Gene clustering analysis in human osseous remodeling. J. Periodontol. 2009, 80, 1998-2009. [CrossRef] [PubMed]

4. Soory, M. Association of periodontitis with rheumatoid arthritis and atherosclerosis: Novel paradigms in etiopathogeneses and management? Open Access. Rheumatol. 2010, 2, 1-6. [CrossRef] [PubMed]

5. Chapple, I.L.C.; Genco, R.; Working group 2 of the joint EFP/AAP workshop. Diabetes and periodontal diseases: Consensus report of the Joint EFP. J. Periodontol. 2013, 84, 106-112. [CrossRef]

6. Michaud, D.S.; Liu, Y.; Meyer, M.; Chung, M. Periodontal disease, tooth loss, and cancer risk in male health professionals: A prospective cohort study. Lancet Oncol. 2008, 9, 550-558. [CrossRef]

7. Lee, D.; Jung, K.U.; Kim, H.O.; Kim, H.; Chun, H.K. Association between oral health and colorectal adenoma in a screening population. Medicine (Baltimore) 2018, 97, e12244. [CrossRef] [PubMed]

8. Momen-Heravi, F.; Babic, A.; Tworoger, S.S.; Zhang, L.; Wu, K. Periodontal disease, tooth loss and colorectal cancer risk: Results from the Nurses' Health Study. Int. J. Cancer 2017, 140, 646-652. [CrossRef]

9. Hussan, H.; Clinton, S.K.; Roberts, K.; Bailey, M.T. Fusobacterium's link to colorectal neoplasia sequenced: A systematic review and future insights. World J. Gastroenterol. 2017, 23, 8626-8650. [CrossRef]

10. Ren, H.G.; Luu, H.N.; Cai, H.; Xiang, Y.B. Oral health and risk of colorectal cancer: Results from three cohort studies and a meta-analysis. Ann. Oncol. 2016, 27, 1329-1336. [CrossRef]

11. Ferlay, J.; Soerjomataram, I.; Dikshit, R.; Eser, S. Cancer incidence and mortality worldwide: Sources, methods and major patterns in GLOBOCAN 2012. Int. J. Cancer 2015, 136, 359-386. [CrossRef]

12. Guo, Y.; Bao, Y.; Ma, M.; Yang, W. Identification of Key Candidate Genes and Pathways in Colorectal Cancer by Integrated Bioinformatical Analysis. Int. J. Mol. Sci. 2017, 18, 722. [CrossRef] [PubMed]

13. Krzystek-Korpacka, M.; Diakowska, D.; Kapturkiewicz, B.; Bebenek, M.; Gamian, A. Profiles of circulating inflammatory cytokines in colorectal cancer (CRC), high cancer risk conditions, and health are distinct. Possible implications for CRC screening and surveillance. Cancer Lett. 2013, 337, 107-114. [CrossRef] [PubMed]

14. Triantafillidis, J.K.; Nasioulas, G.; Kosmidis, P.A. Colorectal cancer and inflammatory bowel disease: Epidemiology, risk factors, mechanisms of carcinogenesis and prevention strategies. Anticancer Res. 2009, 29, 2727-2737. [PubMed]

15. Abraham, C.; Cho, J.H. Inflammatory bowel disease. N. Engl. J. Med. 2009, 361, 2066-2078. [CrossRef]

16. Li, S.K.H.; Martin, A. Mismatch repair and colon cancer: Mechanisms and therapies explored. Trends. Mol. Med. 2016, 22, 274-289. [CrossRef] [PubMed]

17. Flood, A.; Rastogi, T.; Wirfält, E.; Mitrou, P.; Reedz, J.; Subar, A.; Kipnis, V.; Mouw, T.; Hollenbeck, A.; Leitzmann, M.; et al. Dietary patterns as identified by factor analysis and colorectal cancer among middle-aged Americans. Am. J. Clin. Nutr. 2008, 88, 176-184. [CrossRef]

18. Petersen, P.E.; Ogawa, H. The global burden of periodontal disease: Towards integration with chronic disease prevention and control. Periodontology 2000 2012, 60, 15-39. [CrossRef]

19. Han, B.; Fengm, D.; Yu, X.; Zhang, Y.; Liu, Y. Identification and Interaction Analysis of Molecular Markers in Colorectal Cancer by Integrated Bioinformatics Analysis. Med. Sci. Monit. 2018, 24, 6059-6069. [CrossRef]

20. Covani, U.; Marconcini, S.; Giacomelli, L.; Sivozhelevov, V.; Barone, A.; Nicolini, C. Bioinformatic prediction of leader genes in human periodontitis. J. Periodontol. 2008, 79, 1974-1983. [CrossRef]

21. Bragazzi, N.; Nicolini, C. A Leader Genes Approach-based Tool for Molecular Genomics: From Gene-ranking to Gene-network Systems Biology and Biotargets Predictions. J. Comput. Sci. Syst. Biol. 2013, 6, 1760974. [CrossRef]

22. Szklarczyk, D.; Gable, A.L.; Lyon, D.; Junge, A. STRING v11: Protein-protein association networks with increased coverage, supporting functional discovery in genome-wide experimental datasets. Nucleic Acid. Res. 2019, 47, 607-613. [CrossRef] [PubMed]

23. Lim, W.H.; Liu, B.; Cheng, D.; Williams, B.O. Wnt signalling regulates homeostasis of the periodontal ligament. J. Periodontal Res. 2014, 49, 751-759. [CrossRef] 
24. Chen, H.; Ji, L.; Liu, X.; Zhong, J. Correlation between the rs7101 and rs1063169 polymorphisms in the FOS noncoding region and susceptibility to and prognosis of colorectal cancer. Med. Baltim. 2019, 98, e16131. [CrossRef]

25. Kou, Y.; Zhang, S.; Chen, X.; Hu, S. Gene expression profile analysis of colorectal cancer to investigate potential mechanisms using bioinformatics. Onco Targ. Ther. 2015, 8, 745-752.

26. Song, L.; Yao, J.; He, Z.; Xu, B. Genes related to inflammation and bone loss process in periodontitis suggested by bioinformatics methods. BMC Oral Health 2015, 15, 105. [CrossRef] [PubMed]

27. Hu, E.; Mueller, E.; Oliviero, S.; Papaioannou, V.E.; Johnson, R.; Spiegelman, B.M. Targeted disruption of the c-fos gene demonstrates c-fos-dependent and -independent pathways for gene expression stimulated by growth factors or oncogenes. EMBO J. 1994, 13, 3094-3103. [CrossRef] [PubMed]

28. Weinberg, B.A.; Hartley, M.L.; Salem, M.E. Precision Medicine in Metastatic Colorectal Cancer: Relevant Carcinogenic Pathways and Targets-PART 1: Biologic Therapies Targeting the Epidermal Growth Factor Receptor and Vascular Endothelial Growth Factor. Oncol. Williston Park 2017, 31, 539-548.

29. Jiang, H.; Dong, L.; Gong, F.; Gu, Y.; Zhang, H. Inflammatory genes are novel prognostic biomarkers for colorectal cancer. Int. J. Mol. Med. 2018, 42, 368-380. [CrossRef]

30. Pyrc, K.; Milewska, A.; Kantyka, T.; Sroka, A.; Maresz, K. Inactivation of epidermal growth factor by Porphyromonasgingivalis as a potential mechanism for periodontal tissue damage. Infect. Immun. 2013, 81, 55-64. [CrossRef]

31. Zeng, Q.; Lei, F.; Chang, Y.; Gao, Z. An oncogenic gene, SNRPA1, regulates PIK3R1, VEGFC, MKI67, CDK1 and other genes in colorectal cancer. Biomed. Pharmacother. 2019, 117, 109076. [CrossRef] [PubMed]

32. Suzuki, A.; Ji, G.; Numabe, Y.; Ishii, K.; Muramatsu, M.; Kamoi, K. Large-scale investigation of genomic markers for severe periodontitis. Odontology 2004, 92, 43-47. [CrossRef] [PubMed]

33. Balkwill, F. TNF-alpha in promotion and progression of cancer. Cancer Metastasis Rev. 2006, 25, 409-416. [CrossRef] [PubMed]

34. Da Silva, M.K.; de Carvalho, A.C.G.; Alves, E.H.P.; Silva, F.; Pessoa, L.; Vasconcelos, D. Genetic Factors and the Risk of Periodontitis Development: Findings from a Systematic Review Composed of 13 Studies of Meta-Analysis with 71,531 Participants. Int. J. Dent. 2017, 2017, 1-9. [CrossRef]

35. Hai Ping, P.; Feng Bo, T.; Li, L.; Hui, Y.N.; Hong, Z. IL-1 $\beta / N F-k b$ signalling promotes colorectal cancer cell growth through miR-181a/PTEN axis. Arch. Biochem. Biophys. 2016, 601, 20-26. [CrossRef] [PubMed]

36. Wilkins, L.M.; Kaye, E.K.; Wang, H.Y.; Rogus, J.; Doucette-Stamm, L. Influence of Obesity on Periodontitis Progression Is Conditional on Interleukin-1 Inflammatory Genetic Variation. J. Periodontol. 2017, 88, 59-68. [CrossRef]

37. Shamoun, L.; Skarstedt, M.; Andersson, R.E.; Wagsater, D.; Dimberg, J. Association study on IL-4, IL-4R $\alpha$ and IL-13 genetic polymorphisms in Swedish patients with colorectal cancer. Clin. Chim. Acta 2018, 487, 101-106. [CrossRef]

38. Yan, Y.; Weng, H.; Shen, Z.H.; Wu, L.; Zeng, X.T. Association between interleukin-4 gene -590 c/t, -33 c/t, and 70-base-pair polymorphisms and periodontitis susceptibility: A meta-analysis. J. Periodontol. 2014, 85, 354-362. [CrossRef]

39. Di Spirito, F.; Sbordone, L.; Pilone, V.; D’Ambrosio, F. Obesity and periodontal disease: A narrative review on current evidence and putative molecular links. Open Dent. J. 2019, 13, 526-536. [CrossRef]

40. Yu, L.L.; Yu, H.G.; Yu, J.P.; Luo, H.S.; Xu, X.M. Nuclear factor-kB p65 (RelA) transcription factor is constitutively activated in human colorectal carcinoma tissue. World, J. Gastroenterol. 2004, 10, 3255-3260. [CrossRef]

41. Tsuchida, S.; Satoh, M.; Takiwaki, M.; Nomura, F. Ubiquitination in Periodontal Disease: A Review. Int. J. Mol. Sci. 2017, 18, 1476. [CrossRef] [PubMed]

42. Jepsen, S.; Caton, J.G.; Albandar, J.M.; Bissada, N.F.; Bouchard, P.; Cortellini, P.; Demirel, K.; de Sancitis, M.; Ercoli, C.; Fan, J.; et al. Periodontal Manifestations of Systemic Diseases and Developmental and Acquired Conditions: Consensus Report of Workgroup 3 of the 2017 World Workshop on the Classification of Periodontal and Peri-Implant Diseases and Conditions. J. Periodontol. 2018, 89, 237-248. [CrossRef] [PubMed]

43. Yoon, A.J.; Cheng, B.; Philipone, E.; Turner, R.; Lamster, I.B. Inflammatory Biomarkers in Saliva: Assessing the Strength of Association of Diabetes Mellitus and Periodontal Status with the Oral Inflammatory Burden. J. Clin. Periodontol. 2012, 39, 434-440. [CrossRef] [PubMed] 
44. Germini, D.E.; Franco, M.I.F.; Fonseca, F.L.A.; de Sousa Gehrke, F.; da Costa Aguiar Alves Reis, B.; Cardili, L.; Oshima, C.T.F.; Theodoro, T.R.; Waisberg, J. Association of expression of inflammatory response genes and DNA repair genes in colorectal carcinoma. Tumour. Biol. 2019, 41. [CrossRef]

45. Kojima, M.; Morisaki, T.; Sasaki, N.; Nakano, K.; Mibu, R.; Tanaka, M.; Katano, M. Increased nuclear factor-kB activation in human colorectal carcinoma and its correlation with tumor progression. Anticancer Res. 2004, 24, 675-682. [PubMed]

46. Lauritano, D.; Sbordone, L.; Nardone, M.; Iapichino, A.; Scapoli, L.; Carinci, F. Focus on periodontal disease and colorectal carcinoma. Oral Implantol. 2017, 10, 229-233. [CrossRef]

47. Hu, J.M.; Shen, C.J.; Chou, Y.C.; Hung, C.F.; Tian, Y.F. Risk of colorectal cancer in patients with periodontal disease severity: A nationwide, population-based cohort study. Int. J. Colorectal Dis. 2018, 33, 349-352. [CrossRef]

48. Taylor, G.W.; Borgnakke, W.S. Periodontal Disease: Associations with Diabetes, Glycemic Control and Complications. Oral Dis. 2008, 14, 191-203. [CrossRef]

49. Chi, Y.C.; Chen, J.L.; Wang, L.H.; Chang, K.; Wu, C.L. Increased risk of periodontitis among patients with Crohn's disease: A population-based matched-cohort study. Int. J. Colorectal Dis. 2018, 33, 1437-1444. [CrossRef]

50. Glick, M.; Williams, D.M.; Kleinman, D.V.; Vujicic, M.; Watt, R.G.; Weyant, R.J. A New Definition for Oral Health Developed by the FDI World Dental Federation Opens the Door to a Universal Definition of Oral Health. Am. J. Orthod. Dentofac. Orthop. 2017, 151, 229-231. [CrossRef]

51. Barros, S.P.; Williams, R.; Offenbacher, S.; Morelli, T. Gingival Crevicular as a Source of Biomarkers for Periodontitis. Periodontol. 2000 2016, 70, 53-64. [CrossRef] [PubMed]

(C) 2020 by the authors. Licensee MDPI, Basel, Switzerland. This article is an open access article distributed under the terms and conditions of the Creative Commons Attribution (CC BY) license (http://creativecommons.org/licenses/by/4.0/). 